\title{
Review \\ The Role and Significance of Bioumoral Markers in Prostate Cancer
}

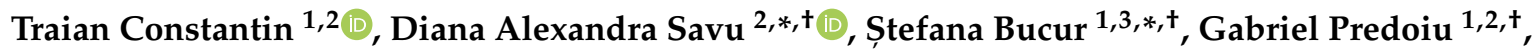 \\ Maria Magdalena Constantin ${ }^{1,3, *}$ and Viorel Jinga ${ }^{1,2}$
}

1 Faculty of General Medicine, "Carol Davila" University of Medicine and Pharmacy, 050474 Bucharest, Romania; traian.constantin@umfcd.ro (T.C.); gabriel.predoiu@drd.umfcd.ro (G.P.); viorel.jinga@umfcd.ro (V.J.)

2 Department of Urology, "Prof. Dr. Theodor Burghele" Hospital, 050659 Bucharest, Romania

3 IInd Department of Dermatology, Colentina Clinical Hospital, 020125 Bucharest, Romania

* Correspondence: diana-alexandra.savu@rez.umfcd.ro (D.A.S.); stefana.bucur@umfcd.ro (S..B.); maria.constantin@umfcd.ro (M.M.C.)

+ These authors contributed equally to this work.

Citation: Constantin, T.; Savu, D.A.; Bucur, S.; Predoiu, G.; Constantin,

M.M.; Jinga, V. The Role and

Significance of Bioumoral Markers in Prostate Cancer. Cancers 2021, 13, 5932. https://doi.org/10.3390/ cancers13235932

Academic Editors: Channing Judith Paller and Pedro C. Barata

Received: 9 August 2021

Accepted: 22 November 2021

Published: 25 November 2021

Publisher's Note: MDPI stays neutral with regard to jurisdictional claims in published maps and institutional affiliations.

Copyright: (c) 2021 by the authors. Licensee MDPI, Basel, Switzerland. This article is an open access article distributed under the terms and conditions of the Creative Commons Attribution (CC BY) license (https:// creativecommons.org/licenses/by/ $4.0 /)$.
Simple Summary: Prostate cancer (PCa) represents a very important health problem worldwide. Used as the main screening method for almost four decades, PSA (Prostate Specific Antigen) has proven its limitations. In this review, the authors try to make an evaluation of the biomarkers commercially available and used to improve the PCa detection in patients with elevated PSA. The authors also present the current PCa screening and diagnosis protocols in Romania.

Abstract: The prostate is one of the most clinically accessible internal organs of the genitourinary tract in men. For decades, the only method of screening for prostate cancer (PCa) has been digital rectal examination of 1990s significantly increased the incidence and prevalence of PCa and consequently the morbidity and mortality associated with this disease. In addition, the different types of oncology treatment methods have been linked to specific complications and side effects, which would affect the patient's quality of life. In the first two decades of the 21st century, over-detection and over-treatment of PCa patients has generated enormous costs for health systems, especially in Europe and the United States. The Prostate Specific Antigen (PSA) is still the most common and accessible screening blood test for PCa, but with low sensibility and specificity at lower values $(<10 \mathrm{ng} / \mathrm{mL})$. Therefore, in order to avoid unnecessary biopsies, several screening tests (blood, urine, or genetic) have been developed. This review analyzes the most used bioumoral markers for PCa screening and also those that could predict the evolution of metastases of patients diagnosed with PCa.

Keywords: prostate cancer detection; screening; bioumoral markers

\section{Introduction}

Prostate cancer (PCa) was in 2020 the second most common cancer and the fifth leading cause of death among the male population worldwide, accounting for $6.8 \%$ of all male cancer mortality [1]. The highest incidence rates (between 83.4 and 62.5 per 100,000 men) were reported in Northern and Western Europe, the Caribbean, Australia/New Zealand, North America, Southern Africa, and South America, while the lowest rates were in Asia and North Africa [1]. In Eastern Europe, the incidence and mortality rates were 46.4/100,000 (ASR) and 13.7/100,000 (ASR) respectively [1]. In Romania in 2020, there was an incidence rate of PCa of 41.5/100,000 (ASR) with a mortality rate of 10.7/100,000 (ASR) [2]. The well-established risk factors are older age, family history of the disease, and black race or ethnicity [3]. In addition, genetic mutations, such as changes in the breast cancer gene 2 (BRCA2), checkpoint kinase 2 (CHEK2), ataxia telangiectasia mutated (ATM), and the breast cancer gene 1 (BRCA1) are present in diagnosed patients with PCa [4]. The 
presence of genetic conditions such as hereditary prostate cancer (HPC), hereditary breast and ovarian cancer syndrome (HBOC) or Lynch syndrome strongly recommends genetic testing in patients with suspicion of PCa [5]. Diet habits may play a role in PCa-a high consumption of tomatoes and lycopene, soy products, fish, green tea, and coffee having a prevention effect for $\mathrm{PCa}$, while the abuse of grilled or fried meat, dietary supplements, and alcohol represent risk factors for PCa [6]. Patients with diabetes mellitus [7], especially those treated with metformin [8], have a lower risk of $\mathrm{PCa}$, compared to the normal population. Exposure to Agent Orange (a herbicide extensively used in the Vietnam War), has been associated with a high risk of aggressive PCa [9]. PCa is linked with increased incidence and mortality in the heavy smoker population [10]. Inflammatory bowel disease [11] and gonorrhea infection [12] could also be considered risk factors for PCa.

The discovery of Prostate-Specific Antigen (PSA) in the late 1980s and early 1990s revolutionized the diagnosis and management of prostate cancer. Although PSA is not an ideal tumor marker, it is one of the most widely used markers in the diagnosis and follow-up of PCa [13]. PSA testing has limited specificity for the detection of PCa, which has led to unnecessary prostate biopsies (60-75\%), especially in patients with total PSA levels between 4 and $10 \mathrm{ng} / \mathrm{mL}[14,15]$. Elevated PSA levels are detected in 30-50\% of cases of benign prostatic hyperplasia (BPH) and only $25 \%$ of cases are associated with PCa [16].

The correlation between PSA and PCa has decreased over the last 20 years [17]. Total PSA is now an important marker for prostate volume, growth, and results related to benign prostatic hyperplasia $(\mathrm{BPH})[18,19]$. PSA has a high negative predictive value if the value is below the maximum cut-off point of $4 \mathrm{ng} / \mathrm{mL}$. There is an important unsatisfied need to find one or more biomarkers that will be able to correctly identify prostate cancer, and, more specifically, high risk prostate cancer [20].

An ideal biomarker should have a high sensitivity and specificity, it should be a noninvasive and inexpensive test that can accurately differentiate benign tissue from cancerous tissue and aggressive tumors [21]. In this review, we will highlight the novel biomarkers that show promise for early detection and management of prostate cancer (Table 1).

Table 1. Prostate cancer biomarkers used in clinical practice.

\begin{tabular}{ccc}
\hline Biomarker & Role & Sample \\
\hline Prostate Specific Antigen (PSA) & Screening & Blood \\
Free/Total PSA ratio (\%fPA) & Diagnosis & Blood \\
PSA density & Diagnosis & Blood \\
PSA velocity & Diagnosis & Blood \\
PSA doubling time & Prognosis & Blood \\
Iso PSA & Recurrence predictor & Blood \\
Alkaline Phosphatase (ALP) & Diagnosis & Blood \\
Prostate specific membrane & Predictor of high risk PCa & Tissue \\
antigen (PSMA) & Prognosis of bone metastatic PCa & Blood (circulating tumor cells) \\
Prostate Cancer Antigen 3 (PCA3) & Diagnosis of metastatic disease & Urine \\
Androgen receptor variant 7 (AR V-7) & Prognosis & Tissue
\end{tabular}

\section{PSA and PSA Derivatives}

\subsection{Total PSA}

PSA, also known as human kallikrein 3, is a blood-circulating glycoprotein which is bound to some protease inhibitors, including $\alpha 1$-antichymotrypsin and $\alpha 2$-macroglobulin. The FDA first approved Prostate-specific antigen screening in 1986 as a prognostic marker for PCa. The introduction of PSA in PCa screening and diagnosis represented a revolution in the disease management, with a significant increase of PCa's incidence and prevalence due to patients' diagnosis in earlier stages, resulting in a reduction in mortality rates [22]. 
Although PSA is not cancer-specific, it is organ-specific. Non-malignant diseases, such as prostatitis, BPH, urinary tract infections or iatrogenic maneuvers (prostate biopsy, bladder catheterization, and urethrocystoscopy) may increase PSA values [23].

The accepted normal range for tPSA is $0-4 \mathrm{ng} / \mathrm{mL}$, although there is no general consensus on these values. In approximately $20-25 \%$ of cases with PCa, the tPSA value is less than $4 \mathrm{ng} / \mathrm{mL}$; tPSA values of $4-10 \mathrm{ng} / \mathrm{mL}$ and over $10 \mathrm{ng} / \mathrm{mL}$ were observed in $67 \%$ of patients [24]. tPSA is important in evaluating the oncological treatment outcomes (surgery, radiotherapy, hormone therapy, chemotherapy) in patients confirmed with PCa [25]. In Romania, according to the Ministry of Heath guidelines, PSA detection is used for the PCa screening (Figure 1), but also for the surveillance of patients confirmed with PCa, regardless of the chosen treatment method [26].

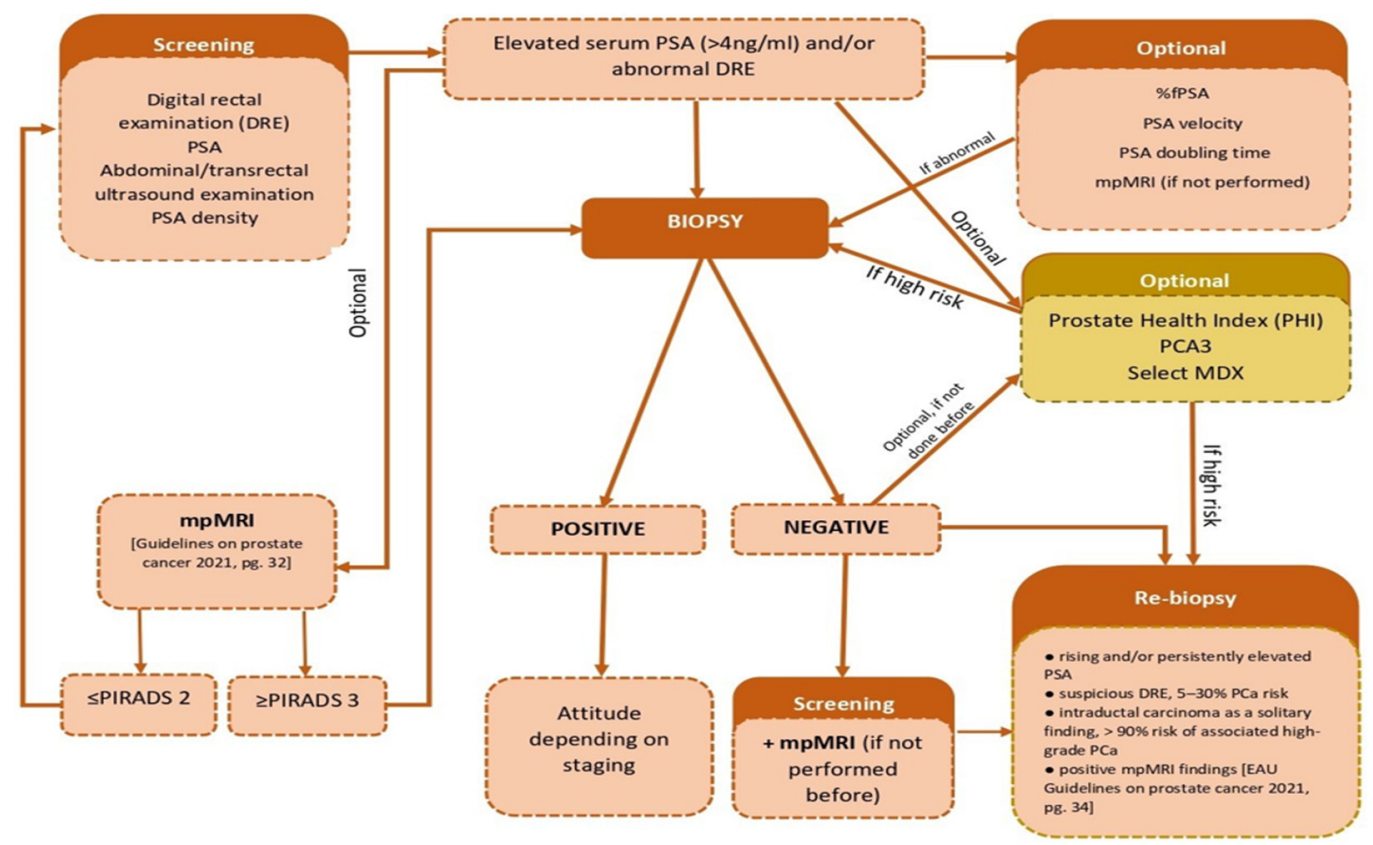

Figure 1. PCa screening and diagnosis protocol in Romania [26]. Abbreviations: PSA, Prostate Specific Antigen; \% \%PA, free to total PSA ratio; PCA3, prostate cancer antigen 3; PHI, Prostate Health Index; mpMRI, multiparametric magnetic resonance imaging; PCa, prostate cancer; PIRADS, Prostate Imaging-Reporting and Data System.

Prostate biopsy is performed for clinical and/or biochemical suspicion of prostate cancer. Multiparametric magnetic resonance imaging (mpMRI) is usually recommended before biopsy, but is not a mandatory investigation. \%fPSA, PSA velocity, and PSA doubling time are optional, but commonly used. In Romania, PHI, PCA3 and Select MDX tests are available in private clinics (performed before biopsy or as additional tests in patients with negative results, but with continuous PCa suspicion), but they are not used in common practice due to significant costs. If not performed before, $\mathrm{mpMRI}$ is strongly recommended for patients with previous negative biopsy and PCa suspicion.

\subsection{Free PSA and Free/Total PSA Ratio}

Serum PSA circulates in a higher percentage bound to one or several proteins, most commonly alpha-1-antichymotrypsin (ACT) and also in unbound "free" form [27]. Free PSA (fPSA) constitutes $5-40 \%$ of the total PSA. The $\mathrm{f} / \mathrm{tPSA}$ ratio formula is expressed as $\% \mathrm{fPSA}=100 \times \mathrm{fPSA} / \mathrm{tPSA}$. Studies have shown that $\% \mathrm{fPSA}$ is lower in men with prostate cancer than benign prostatic pathologies (especially BPH) [28]. Therefore \%fPSA has shown the potential to discriminate between benign and malignant prostatic disease [28].

Especially in men with PSA levels in the "diagnostic grey zone" (PSA $=4.0-10.0 \mathrm{ng} / \mathrm{mL}$ ), $\mathrm{f} / \mathrm{tPSA}$ exceeded total PSA because it is more sensitive to PCa discrimination from benign 
tissues [29]. For a threshold value of $25 \%, \mathrm{f} / \mathrm{tPSA}$, had a sensitivity of $95 \%$ and a specificity of $20 \%$ for PCa diagnosis in patients with a PSA value between 4 and $10 \mathrm{ng} / \mathrm{mL}$ [30]. The potential benefit of using \% fPSA consisted in avoiding the unnecessary biopsies in patients undergoing prostate cancer evaluation [31].

One prospective multicenter study conducted in 1998 revealed that \%fPSA decreased the rate of unnecessary biopsies by $20 \%$ when using a $25 \%$ cutoff point of the ratio. Another result of the study showed that cases with prostate cancer identified at a ratio of more than $25 \%$ were reduced in numbers, and, they had low risk prostate cancers [32].

According to the National Academy of Clinical Biochemistry (NACB), the use of $\%$ fPSA is recommended to differentiate patients with a suspicion of prostate cancer from those with BPH, when total serum PSA levels are between 4-10 ng/mL [33]. In our clinical practice this ratio has some utility to identify potential prostate cancer cases if the PSA is in the gray interval. This must be interpreted in a given clinical scenario and although it is not diagnostic, it offers some extra information to make a decision regarding the recommendation of prostate biopsy. The Romanian Ministry of Health includes \%fPSA as an optional investigation for PCa screening [26].

\subsection{Complexed PSA (cPSA)}

Complexed PSA is found in serum in a conjugated form (60-90\% bound to antichymotrypsin, 10-20\% alpha-2-macroglobulin and 1-5\% alpha-1-protease inhibitor) and constitutes $60-95 \%$ of total PSA [34]. Several studies have shown that cPSA enhances the specificity of tPSA in men with tPSA greater than $4 \mathrm{ng} / \mathrm{mL}$ and within clinically relevant tPSA ranges of 4-10 $\mathrm{ng} / \mathrm{mL}$ and $2.5-4 \mathrm{mg} / \mathrm{mL}[35,36]$.

A prospective multicenter study, based on 831 patients showed that using a cutoff point of $2.5 \mathrm{ng} / \mathrm{mL}$ for total PSA and $2.2 \mathrm{ng} / \mathrm{mL}$ for Complexed PSA, with the cPSA range between 1.5 to $3.2 \mathrm{ng} / \mathrm{mL}$ provided a specificity of $21.2 \%$ and $35 \%$, respectively, and a sensitivity of $85 \%$ for prostate cancer detection [36].

\subsection{Age-Specific PSA}

It has been shown in studies in the late 1990s that with age-related prostate growth (volume), there is a logarithmic increase in serum tPSA [37]. A further investigation of this finding showed that creating age-related cut-off points for total PSA may lead to an increased sensitivity of detecting prostate cancer in younger men, and reduce unnecessary prostate biopsy procedures in patients over 70 years of age [38]. Although there is some evidence to support the use of age-adjusted reference intervals, they are not frequently used in clinical practice and do not appear to have a standardized application. Further investigations are needed in this regard, but age-related PSA intervals appear to be an inexpensive way to add further value to PSA screening [39].

\subsection{PSA Doubling Time (PSADT)}

It is defined as the time required for serum PSA to double its value. The formula used to calculate PSADT IS [ $\log (2)^{*} \mathrm{~T} 2-\mathrm{T} 1$ (time difference)]/[log PSA2 - logPSA1]. It is considered to be more useful in the treatment stages and to monitor the recurrence of prostate cancer, rather than the diagnosis [40].

\subsection{PSA Velocity (PSAV)}

First described by Carter et al. in 1992, PSA velocity is defined as the absolute annual increase in PSA, measured in $\mathrm{ng} / \mathrm{mL} /$ year [41]. At a cut-off point of $\geq 0.3-0.5 \mathrm{ng} / \mathrm{mL} /$ year the PSAV specificity was $90 \%$ in the monitoring of patients with prostate cancer, compared to $60 \%$ if total PSA was used [42]. Even successfully used in PCa prediction, the usefulness of PSAV in screening is still controversial [43]. PSAV has been shown to have little to no value as an independent predictor of a positive prostate biopsy result, as shown by The European Randomized Study of Screening for Prostate Cancer (ERSPC) [44]. 


\subsection{PSA Density (PSAD)}

PSAD, introduced in the early 1990s by Benson et al. has increased the accuracy of PSA diagnosis and is defined as the ratio of PSA concentration to prostate volume [45]. It is a better predictor of PCa than PSA, but has not been used in common practice over the years [46]. PSA density of the transition zone (PSADTZ), described by Kalish et al. had a better prediction for positive biopsy than conventional PSAD, in patients with PSA levels in the "grey zone" (4.0-10.0 ng/mL) [47]. Other studies have shown that PSADTZ was superior compared to PSAD in discriminating PCa from BPH [48]. Despite these positive findings, PSAD does not currently occur in clinical practice, although it is used in academic investigations.

\subsection{ProPSA ( $p P S A)$}

ProPSA is a precursor of PSA that contains 244 amino acids released from peripheral malignant tissue rather than the hyperplastic areas developed in the transitional zone [49]. ProPSA has many subfractions, for example, [-2]Ppsa-described by Mikolajczyk et al., which was first found in prostate cancer tissue and has the most stable form in serum [50]. ProPSA is more often associated with peripheral zone cancer than transition zone hyperplasia [51]

A prospective study of 566 subjects diagnosed with $\mathrm{PCa}$, detected on biopsy, showed that with a sensitivity of $80 \%, \%[-2]$ proPSA had a higher specificity $(51.6 \%)$, compared to PSA (29.9\%) and \%fPSA (28.9\%) [52].

The use of tPSA and its derivatives for PCa detection is still common in most countries. Other blood and urine tests have been developed to avoid unnecessary prostate biopsies with a concurrent reduction in the risk of complications after this procedure (Table 2).

Table 2. Serum and urinary biomarkers that may increase the accuracy of prostate cancer diagnosis.

\begin{tabular}{ccc}
\hline Test & Analytes Detected & Fluid \\
\hline Prostate Health Index (PHI) & PSA, fPSA, [-2]ProPSA & Serum \\
Prostate cancer antigen (PCA3) & PCA3 & Urine collected after prostate massage \\
Four-kallikrein panel (4K Score) & PSA, fPSA, iPSA, khK2 & Serum or plasma \\
MiPS & PCA3, TMPRSS2-ERG & Urine \\
Stockholm-3 (STHLM3) & PSA, fPSA, hK2, MIC 1, MSMB, genetic markers & Serum \\
\hline
\end{tabular}

Abbreviations: fPSA, free PSA; [-2]ProPSA, ProPSA; hK2, human kallikrein 2; iPSA, intact PSA; PCa, prostate cancer; PCA3, prostate cancer antigen 3; PHI, Prostate Health Index; PSA, Prostate Specific Antigen; MiPS, Mi-Prostate Score; TMPRSS2-ERG-The transmembrane protease serine 2:v-ets erythroblastosis virus E26 oncogene homolog gene fusion; MIC 1, macrophage inhibitory cytokine-1; MSMB, $\beta$-microseminoprotein.

\section{9. isoPSA}

It is a well-established fact that PSA has multiple isoforms. Testing for PSA isoforms is a well-documented and possible choice when it comes to biomarkers that are involved in prostate cancer diagnosis and prognosis. Thus, testing for isoforms that we know of, for example PHI and 4KScore, is a common clinical tool to be used by the attending physician. The major problem with testing for only for what we know in terms of PSA isoforms is that they are only useful if they are present in that specific patient [53].

It is a well-established fact that proteins associated with cancer processes undergo significant structural changes due to point mutations, truncations, and post-translational modifications [54,55]. This will lead to altered metabolism of cancer cells and different protein interactions.

IsoPSA is a blood based, structure-oriented assay that predicts the risk of high-risk prostate cancer by partitioning the isoforms of prostate specific antigen that are associated with prostate cancer [56].

Clinical validation studies have shown that isoPSA structure assay is highly more effective than concentration-based PSA testing or free PSA to PSA ration in detecting high grade prostate cancer. isoPSA showed good values on ROC analysis with an AUC of 0.784 which was shown to be improved on subset analysis of MRI fusion guided prostate biopsy to an AUC of 0.831 [57]. 


\section{Alkaline Phosphatase (ALP)}

ALP is an enzyme that under physiological conditions can dephosphorylate compounds under alkaline conditions [58]. It is widely used in liver and bone diseases, and has been investigated as a potential biomarker in metastatic prostate cancer [59].

It has been postulated that ALP might be used as a biomarker in the setting of bone metastatic prostate cancer. A meta-analysis of prostate cancer studies which looked at the usefulness as a biomarker of alkaline phosphatase, included 63 studies $(16,135$ patients summed up) and showed that high levels of alkaline phosphatase were clearly associated with a poor overall survival and progression free survival, but found no statistical relationship with cancer specific survival [60].

In Romania, ALP is widely used for the surveillance of the treatment outcome in bone metastatic PCa.

\section{Prostate Specific Membrane Antigen (PSMA)}

PSMA is a transmembrane protein structure that is expressed in all forms of prostatic tissue, including carcinoma. It currently represents a very important target for the administration of personalized treatment of metastatic prostate cancer, by binding PSMA ligands to radionucleotides [61].

Retrospective analysis of prostate cancer samples for PSMA expression supports its utility as a prognostic tissue biomarker suggestive of lethal disease, correlating with higher Gleason score and PSA at diagnosis [62]. It has also been observed that PSMA expression is higher in lymph node metastasis of prostate cancer and has been associated with a reduced time to biochemical recurrence [63].

PSMA expression can be measured in circulating tumor cells and it has been associated with shorter progression, free survival, and overall survival and castrate-resistant metastatic disease [64]. Additionally, the overall expression of PSMA is considered to be a surrogate indicator of the poor response to the currently approved medication of metastatic Castration-Resistant Prostate Cancer (mCRPC) [64].

PSMA as a biomarker shows potential, especially in mCRPC settings. Additionally, it is a very important target and response to treatment in the upcoming field of theranostics [65].

\section{Prostate Health Index (PHI)}

Prostate Health Index (PHI) is a mathematical formula that combines three different forms of PSA: total PSA, free PSA, and [-2]proPSA [66]. PHI is calculated using the following equation: ([-2]proPSA/PSA free) $\times \sqrt{ }$ PSA [67]. PHI was recognized by the FDA in June 2012 as an efficient clinical test for the early detection of prostate cancer in men $>50$ years of age, with PSA levels between 4.0 and $10.0 \mathrm{ng} / \mathrm{mL}$ and without any clinical modification on the digital rectal examination (DRE) of the prostate [68].

PHI shows to be superior to tPSA and \%fPSA in predicting the presence of prostate cancer, including aggressive forms [69]. A meta-analysis of eight studies concluded that the PHI sensitivity for prostate cancer diagnosis was $90 \%$, while the specificity was $31.6 \%$ [70]. In addition, PHI had a higher accuracy for prostate cancer detection, especially for patients with PSA levels between $2 \mathrm{ng} / \mathrm{mL}$ and $10 \mathrm{ng} / \mathrm{mL}$ [70].

$\mathrm{PHI}$ also proved to have a higher predictive accuracy for an aggressive disease (Gleason score $\leq 8)$ than PSA and \% free PSA [71]. Loeb et al. reported that the PHI specificity was $36 \%$ compared to $17.2 \%$ for PSA and $19.4 \%$ for \%fPSA in the detection of high-risk PCa [71]. For a cut-off value of 24, PHI measurement could spare $36-41 \%$ of unnecessary biopsies and $17-24 \%$ of over diagnosed low risk cancers [72].

The main clinical use of PHI is to avoid unnecessary biopsies in men with PSA levels in the "grey zone" and this value can range from $15 \%$ to $46 \%$, depending on the cut-off point used [73]. Currently, $\mathrm{PHI}$ is not recommended to be used in the initial screening for $\mathrm{PCa}$, but it may be considered in the next years as an efficient evaluation method for patients with PSA values between $2 \mathrm{ng} / \mathrm{mL}$ and $10 \mathrm{ng} / \mathrm{mL}$ [74]. 
Currently in Romania, PHI is not used in common practice and is available in selected private urology clinics.

\section{Prostate Cancer Antigen 3 (PCA3)}

Prostate cancer antigen 3 (PCA3), or DD3 (Differential Display Code 3), is a noncoding RNA produced almost exclusively in the prostate tissue. Bussemakers et al., who first identified and described it in 1999, also proved that the PCA3 gene is significantly overexpressed in malignant tissue compared to normal prostate [75].

In order to measure PCA3 mRNA, a urine sample obtained after a prostate massage is analyzed using real-time quantitative polymerase chain reaction (qRT-PCR) technique. This method is used because digital rectal examination induces pressure inside the prostate, resulting in the release of prostate cells through the prostate ducts and into the urethra [76]. The Progensa PCA3 test was approved by the FDA in 2012 and is a semi-automated assay that includes the isolation, amplification, hybridization, and quantification of PCA3 and PSA mRNAs using DTS systems [77].

A PCA3 score uses the ratio of PCA3 mRNA to PSA concentration (PCA3/PSA $\times 1000)$ [78]. The ideal cutoff score used for PCA3 is still controversial. The most appropriate cutoff for the PCA3 score recommended by the FDA is less than 25 and is associated with a low probability of a positive biopsy. Roobol et al. showed that PCA3 sensitivity significantly increased by lowering the cut-off values $(68 \%, 84 \%$, and $97 \%$ for the cut-offs of 35,20 , and 10, respectively) [79]. These authors also suggested that $26 \%$ of aggressive prostate cancer cases were missed using the cutoff of 35 [79]. Although its role in screening and surveillance remains unclear, PCA3 may serve as a valuable biomarker that goes further.

PCA3 mRNA detection is available in Romania.

\section{Michigan Prostate Score (MiPS)}

MiPS was developed by Tomlins et al. and the results were published in 2015 [80]. It is an assay that incorporates serum PSA level, urine PCA3 mRNA, and urine TMPRSS2ERG [80]. The urine sample that is used in this test should be taken no later than $1 \mathrm{~h}$ after the digital rectal examination. The score is designed for men with high PSA levels with an indication of initial biopsy or for patients who are considering repeating the biopsy. A score between 1 and 100 reflects the percentage chance of prostate cancer on biopsy [81]. Therefore, while MiPS certainly provides value over PSA alone, its diagnostic value over PCA3 still requires validation [82].

The MiPS AUC was 0.751 compared to PSA, PSA plus T2:ERG score and PSA plus PCA3 score AUCs $(0.585,0.693$ and 0.726 respectively, $p$ value $<0.05)$ [80].

In an earlier study, Salami et al. showed that incorporating PSA, PCA3, and TMPRSS2ERG in a multivariable algorithm is more specific than any of them as individual variables with a specificity of $90 \%$ and a sensitivity of $80 \%$ [77].

\section{4Kscore (Four Kalikrein Panel)}

The 4Kscore represents a serum-based biomarker that associates multiple factors: age, digital rectal examination aspect, results of previous prostate biopsies, measurements of tPSA, free PSA, intact PSA, which is a form of free PSA, and human kallikrein 2 (hK2) that has promising results in PCa detection. [83]. A significant number of studies revealed that the 4Kscore is an important predictor of the diagnosis of intermediate and high-grade cancer (Gleason Score $\geq 7$ ) in prostate biopsy [84]. At a PSA value higher than $3 \mathrm{ng} / \mathrm{mL}$, the biomarker is more sensitive in the detection of high-grade prostate cancer than clinical variables individually [85]. A 4 Kscore of $\geq 20$ indicate high-risk disease and the necessity for prostate biopsy. On the other hand, values between 1-7.5 are considered low risk [86].

A prospective multi-institutional study conducted in the US, which included and evaluated 1012 patients undergoing prostate biopsy, confirmed the value of the 4Kscore [87]. At a cut-off value of $6 \%$, approximately $30 \%$ of biopsies could be avoided, delaying the diagnosis for $1.3 \%$ of patients with high-grade prostate cancer [87]. 
A study based on 137 patients revealed that using $7.5 \%$ as a cutoff for the $4 \mathrm{~K}$ score, the sensitivity of the multiparametric biomarker is $89 \%$ and the specificity is $29 \%$ [88].

Compared to PHI, a meta-analysis revealed that the accuracy of the diagnosis is similar for both tests [89]. It was established that the $4 \mathrm{~K}$ score has a significant role in avoiding unnecessary prostate biopsies and has been reported to range from $49 \%$ to $57 \%$, depending on the cut-off value used [90].

\section{The Stockholm-3 Model, or STHLM3}

The Stockholm-3 Model, or STHLM3, is a commercially available laboratory test, which is basically a statistical model that considers clinical, laboratory testing and genetic profile. Predictive factors used in the Stockholm-3 Model include clinical information (age, first degree-family history of prostate cancer and previous biopsy), blood biomarkers (total PSA, free PSA, free PSA to PSA ratio, hK2, macrophage inhibitory cytokine-1 (MIC 1) and $\beta$-microseminoprotein (MSMB)), genetic markers (a genetic score based on 254 single nucleotide polymorphism and a specific score for the HOXB13 SNP) and information from prostate examination (digital rectal examination and prostate volume measured using MRI examination) [91].

The main clinical utility of STHLM3 is to reduce the number of unnecessary prostate biopsies and increase diagnosis of clinically significant prostate cancer. The negative predictive value of STHLM3 was calculated at 92\% in one study [92].

\section{Androgen Receptor Variant 7 (AR V-7)}

Androgen receptor variant 7 is the most identified mutation that will lead to castration resistant prostate cancer. Knowing the expression of Androgen Receptors variants is a useful clinical tool that can help guide the change of therapeutic agents during treatment sequencing.

AR-V7 can be identified by immunohistochemistry in prostate tissue or metastatic tumors. It was shown that androgen receptor splice variant 7 was commonly observed in metastatic tumors [93]. Given the practical and technical challenges associated to metastatic tumor biopsy, AR-V7 splice variants can be measured more easily by "liquid biopsy" [94]. In a peripheral blood sample, the expression of AR-V7 can be measured in circulating tumor cells.

Several studies have assessed the utility of AR-V7 as a biomarker for metastatic castrate resistant prostate cancer and it was considered useful for the decision making in regard to treatment sequencing [95].

\section{Genetic Panels in Prostate Cancer Prognosis}

Currently, genetic tests with an important role in the diagnosis and prognosis of the disease are used in common practice, but due to cost, complexity, and accessibility, they are not available for all categories of patients (Table 3).

Table 3. Genetic tests used in the prognosis of PCa.

\begin{tabular}{ccc}
\hline Test & Role & Sample \\
\hline Prolaris & $\begin{array}{c}\text { Prognosis } \\
\text { Oncotype DX_GPS }\end{array}$ & Tissue \\
& $\begin{array}{c}\text { Predictor of high risk disease } \\
\text { Prognosis }\end{array}$ & Tissue \\
Decipher & $\begin{array}{c}\text { Prognosis } \\
\text { Predictor of high risk disease } \\
\text { Indicator for treatment } \\
\text { Select MDX }\end{array}$ & Diagnosis \\
& Predictor of high risk disease & Tissue \\
\hline
\end{tabular}


The Prolaris test evaluates the expression of 31 genes that are part of a cell-cycle progression (CCP), an essential step in the cancer development and evolution and it represents a more potent prognostic factor than PSA [96]. The test generates a score with values from -3 to +3 , based on modifications in gene expression levels. A higher score predicts adverse events in patients following treatment for PCa [97].

The Prolaris test, performed on tissue samples obtained after prostate biopsy or radical prostatectomy, could be useful in establishing the indication for active surveillance or active treatment in patients with low-risk PCa [98]. The test could also be useful for high-risk patients as it may suggest adjuvant therapy [98]. National Comprehensive Cancer Network (NCCN) guidelines recommend using the Prolaris test for very-low and low-risk PCa patients with positive biopsies and a life expectancy higher than ten years [99].

The Oncotype DX test (Genomic Prostate Score-GPS) is an analysis based on the detection of 17 gene panels using real-time PCR, performed on tissue samples obtained by prostate needle biopsy, prepared and fixed in paraffine [100]. GPS measures gene expression in prostate tumors using a scale of 0 to 100 , a higher score indicating a more suggestive pathology. GPS can guide clinicians to separate patients for active surveillance from patients for therapeutic interventions [101]. The GPS score should be combined with other clinical parameters (age, PSA, clinical stage, and biopsy Gleason score) [102].

On radical prostatectomy, the Oncotype DX test predicted intermediate and highgrade (Gleason score $\geq 4+3$ ) and high-stage ( $\geq$ pT3) disease [103]. It has been shown to predict the aggressiveness of cancer on prostate needle biopsy [103]. More than $50 \%$ of the patients with unfavorable intermediate (UFI) risk PCa and GPS score above 40 will have biochemical recurrence at 10 years, while $25 \%$ will develop metastatic disease, compared to patients with scores below 40 [104]. The NCCN guidelines suggested that Oncotype DX could be used after biopsy, for patients with very-low and low-risk disease and high life expectancy (10 to 20 years) [105].

Decipher is a tissue-based genomic test that includes 22-gene-expression signatures identified and associated with aggressive PCa after prostate biopsy and/or radical prostatectomy. It was codeveloped and validated by GenomeDx Biosciences and Mayo Clinic and it is approved as a prediction tool for the risk of metastasis development after surgery. The test generates a risk score with values between 0 and 1 (with increments of 0.1) [106]. Decipher represents a significant prognostic factor for early metastatic disease and, for PCa specific death [106].

Dalela et al. developed a risk stratification tool (a score with values between 1 and 4) that helps to identify the patients who could benefit from adjuvant radiotherapy versus initial observation. It is based on the cumulative number of lymph node invasion, pT3b/T4 disease, pathological Gleason score 8-10 and Genomic Classifier Decipher >0.6 [107].

Adjuvant radiotherapy reduced the 10-year clinical recurrence rate only in patients with a risk score equal to or greater than 2 , suggesting that patients with a higher decipher score and unfavorable pathological characteristics should be considered for adjuvant treatment [108]. NCCN guidelines recommend using Decipher in patients with positive surgical margins (R1), any pT3 disease, or rising PSA after radical prostatectomy [99].

A review of 42 studies concluded that the Decipher genomic classifier score higher than 0.6 after localized treatment is a strong predictive factor for biochemical failure (defined as two consecutive PSA values of more than $0.2 \mathrm{ng} / \mathrm{mL}$ in patients who underwent radical prostatectomy [109] or any increase in PSA greater than or equal to $2 \mathrm{ng} / \mathrm{mL}$ higher than the PSA nadir in patients with radiotherapy [110] and metastatic disease [111]. The NCCN guidelines for PCa (2022) recommend salvage radiotherapy with hormone therapy after radical prostatectomy for patients with a Decipher score higher than 0.6 [112].

Select MDx is a non-invasive post-DRE urine methylation test that is available in clinical practice and improves patient selection for initial biopsy. It measures urinary mRNA levels of the three-gene panel (HOXC6, DLX1, TDRD1), and higher levels are associated with an increased probability of aggressive PCa [113]. The test has $98 \%$ negative predictive value for a Gleason score $\geq 7$ disease and $99 \%$ negative predictive value for 
a Gleason score $\geq 8$ disease, while reducing unnecessary biopsies by up to 53\% [114]. A low-risk SelectMDx score is correlated with a $90 \%$ probability of PCa and, respectively a 98\% high-risk PCa absence [108].

In a more recent prospective study, based on 163 patients, Select MDx was associated with a sensitivity of $76.9 \%$, a specificity of $49.6 \%$ and a negative predictive value of $82 \%$ in the detection of clinically significant prostate cancer. The study also suggested that a combination of the Select MDx test and MRI could improve the accuracy in the detection of prostate cancer [115].

In Romania, the Select MDX test is available, but the costs are not covered by the National Health Insurance System. Therefore, only limited number of patients can benefit from this analysis. In the Urology Department of "Prof. Dr. Theodor Burghele" Clinical Hospital (Bucharest, Romania), the Select MDX test was performed for 120 patients, aged between 45 and 60, with elevated PSA levels (maximum $10 \mathrm{ng} / \mathrm{mL}$ ) and without any clinical modification on digital rectal examination of the prostate. The patients were informed about the possibility of having the test as alternative to prostate multiparameter MRI examination. For the patients from the SelectMDX test group, the preliminary collected data revealed that the unnecessary prostate biopsies were reduced by $25 \%$. The data is still under analysis, further conclusions will be published in a dedicated study.

\section{Conclusions}

In this review, the authors have highlighted some of the numerous promising biomarkers commercially available and used to improve the PCa detection in patients with elevated PSA. Although PSA is currently the most broadly prostate cancer biomarker used for screening, other tests have been introduced into common practice and are being performed more and more extensively (Figure 2).

Complex tests such as PHI, 4Kscore, Stockholm-3 (based on PSA isoforms), PCA3, MiPS (based on PCA3) and Select MDX (genetic test) have an important role in stratifying patients with high risk for $\mathrm{PCa}$, reducing at the same time the number of unnecessary biopsies.

Prolaris, Oncotype DX_GPS and Decipher are essential in the classification of patients diagnosed with PCa in the group of low-risk disease, with the recommendation for active surveillance or in the one with aggressive tumors, which will rapidly need active treatment, even (for Decipher test) adjuvant therapy after surgery.

PSMA and AR-V7 have significant role in the prediction and diagnosis of metastatic PCa, while "old, but very valuable" ALP is an essential marker for bone metastasis.

The management of patients diagnosed with PCa is well defined. However, overdiagnosis and overtreatment of PCa, early detection of the patients with a high-risk disease and early treatment in that category are still important challenges for health systems in all countries, and the extensive use of biomarkers in the diagnosis and prognosis of PCa could be an answer in solving these issues.

In recent years there have been great discoveries in the research of prostate cancer biomarkers; however, further studies are needed to define the appropriate context for their use. Ongoing investigation of these markers and new markers in the future will improve the detection and management of early prostate cancer, providing more accurate results. 


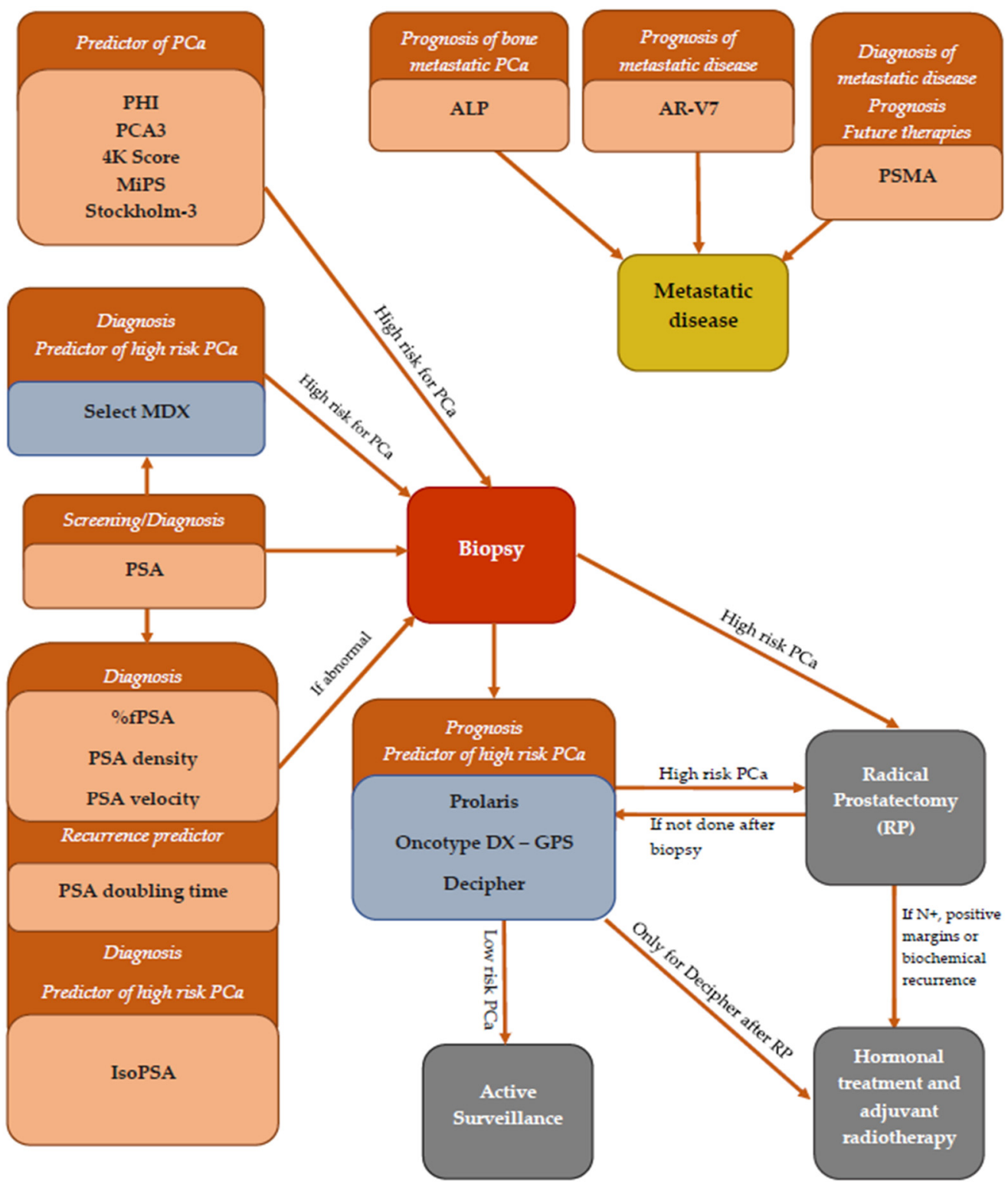

Figure 2. Summary of the most common PCa biomarkers and their use.

Author Contributions: Conceptualization, T.C., D.A.S. and V.J.; Methodology, T.C. and V.J.; WritingOriginal Draft Preparation, D.A.S.; Writing-Review and Editing, S.B., G.P., M.M.C. and D.A.S.; Supervision, T.C. and V.J. All authors have read and agreed to the published version of the manuscript.

Funding: No funding was received.

Conflicts of Interest: The authors declare that there are no conflicts of interest.

\section{References}

1. Sung, H.; Ferlay, J.; Siegel, R.L.; Laversanne, M.; Soerjomataram, I.; Jemal, A.; Bray, F. Global Cancer Statistics 2020: GLOBOCAN Estimates of Incidence and Mortality Worldwide for 36 Cancers in 185 Countries. CA Cancer J. Clin. 2021, 71, 209-249. [CrossRef]

2. World Health Organisation. International Agency for Research on Cancer-Cancer Today-Prostate Cancer. Available online: https:/ /gco.iarc.fr/today/online-analysis-map?v=2020\&mode (accessed on 13 November 2021).

3. Platz, E.A.; Giovannucci, E. Prostate cancer. In Cancer Epidemiology and Prevention; Schottenfeld, D., Fraumeni, J.F., Eds.; Oxford University Press: New York, NY, USA, 2006; pp. 1128-1150.

4. Giri, V.N.; Hegarty, S.E.; Hyatt, C.; O’Leary, E.; Garcia, J.; Knudsen, K.E.; Kelly, W.K.; Gomella, L.G. Germline genetic testing for inherited prostate cancer in practice: Implications for genetic testing, precision therapy, and cascade testing. Prostate 2019, 79, 333-339. [CrossRef] [PubMed] 
5. Giri, V.N.; Knudsen, K.; Kelly, W.K.; Abida, W.; Andriole, G.L.; Bangma, C.H.; Bekelman, J.E.; Benson, M.C.; Blanco, A.; Burnett, A.; et al. Role of Genetic Testing for Inherited Prostate Cancer Risk: Philadelphia Prostate Cancer Consensus Conference 2017. J. Clin. Oncol. 2018, 36, 414-424. [CrossRef] [PubMed]

6. Leitzmann, M.F.; Rohrmann, S. Risk factors for the onset of prostatic cancer: Age, location, and behavioral correlates. Clin. Epidemiol. 2012, 4, 1-11. [CrossRef]

7. Kasper, J.S.; Giovannucci, E. A meta-analysis of diabetes mellitusand the risk of prostate cancer. Cancer Epidemiol. Prev. Biomark. 2006, 15, 2056-2062. [CrossRef]

8. Preston, M.A.; Riis, A.H.; Ehrenstein, V.; Breau, R.; Batista, J.L.; Olumi, A.F.; Mucci, L.A.; Adami, H.-O.; Sørensen, H.T. Metformin Use and Prostate Cancer Risk. Eur. Urol. 2014, 66, 1012-1020. [CrossRef] [PubMed]

9. Ansbaugh, N.; Shannon, J.; Mori, M.; Farris, P.E.; Garzotto, M. Agent Orange as a risk factor for high-grade prostate cancer. Cancer 2013, 119, 2399-2404. [CrossRef]

10. Huncharek, M.; Haddock, K.S.; Reid, R.; Kupelnick, B. Smoking as a risk factor for prostate cancer: A meta-analysis of 24 prospective cohort studies. Am. J. Public Health 2010, 100, 693-701. [CrossRef]

11. Burns, J.A.; Weiner, A.B.; Catalona, W.J.; Li, E.V.; Schaeffer, E.M.; Hanauer, S.B.; Strong, S.; Burns, J.; Hussain, M.H.; Kundu, S.D. Inflammatory Bowel Disease and the Risk of Prostate Cancer. Eur. Urol. 2019, 75, 846-852. [CrossRef]

12. Lian, W.Q.; Luo, F.; Song, X.L.; Lu, Y.J.; Zhao, S.C. Gonorrhea and Prostate Cancer Incidence: An Updated Meta-Analysis of 21 Epidemiologic Studies. Med Sci. Monit. Int. Med. J. Exp. Clin. Res. 2015, 21, 1895. [CrossRef]

13. Rao, A.R.; Motiwala, H.G.; Karim, O.M. The discovery of prostate-specific antigen. BJU Int. 2007, 101, 5-10. [CrossRef]

14. Loeb, S.; Bjurlin, M.A.; Nicholson, J.; Tammela, T.L.; Penson, D.; Carter, H.B.; Carroll, P.; Etzioni, R. Overdiagnosis and Overtreatment of Prostate Cancer. Eur. Urol. 2014, 65, 1046-1055. [CrossRef]

15. Matlaga, B.R.; Eskew, L.A.; McCullough, D.L. Prostate biopsy: Indications and technique. J. Urol. 2003, 169, 12-19. [CrossRef]

16. Schröder, F.H. PSA screening-a review of recent studies. Eur. J. Cancer 2009, 45, 402-404. [CrossRef]

17. Noguchi, M.; A Stamey, T.; McNeal, J.E.; Yemoto, C.M. Preoperative serum prostate specific antigen does not reflect biochemical failure rates after radical prostatectomy in men with large volume cancers. J. Urol. 2000, 164, 1596-1600. [CrossRef]

18. Roehrborn, C.G.; Boyle, P.; Gould, A.; Waldstreicher, J. Serum prostate-specific antigen as a predictor of prostate volume in men with benign prostatic hyperplasia. Urol. 1999, 53, 581-589. [CrossRef]

19. Roehrborn, C.G.; McConnell, J.; Bonilla, J.; Rosenblatt, S.; Hudson, P.B.; Malek, G.H.; Schellhammer, P.F.; Bruskewitz, R.; Matsumoto, A.M.; Harrison, L.H.; et al. Serum prostate specific antigen is a strong predictor of future prostate growth in men with benign prostatic hyperplasia. PROSCAR long-term efficacy and safety study. J. Urol. 2000, 163, 13-20. [CrossRef]

20. Shariat, S.F.; Karam, J.A.; Margulis, V.; Karakiewicz, P.I. New blood-based biomarkers for the diagnosis, staging and prognosis of prostate cancer. BJU Int. 2008, 101, 675-683. [CrossRef] [PubMed]

21. Biomarkers Definitions Working Group. Biomarkers and surrogate endpoints: Preferred definitions and conceptual framework. Clin. Pharmacol. Ther. 2001, 69, 89-95. [CrossRef]

22. Bjartell, A.S. Next-generation Prostate-specific Antigen Test: Ready To Use? Eur. Urol. 2013, 64, 700-702. [CrossRef] [PubMed]

23. Oesterling, J.E. Prostate Specific Antigen: A Critical Assessment of the Most Useful Tumor Marker for Adenocarcinoma of the Prostate. J. Urol. 1991, 145, 907-923. [CrossRef]

24. Luderer, A.A.; Chen, Y.-T.; Soriano, T.F.; Kramp, W.J.; Carlson, G.; Cuny, C.; Sharp, T.; Smith, W.; Petteway, J.; Brawer, M.K.; et al. Measurement of the proportion of free to total prostate-specific antigen improves diagnostic performance of prostate-specific antigen in the diagnostic gray zone of total prostate-specific antigen. Urol. 1995, 46, 187-194. [CrossRef]

25. European Association of Urology. Guidelines on Prostate Cancer. Available online: https://uroweb.org/guideline/prostatecancer/ (accessed on 13 November 2021).

26. The Romanian Ministry of Health. Guidelines on Prostate Cancer. Available online: http:/ / old.ms.ro/index.php?pag=181\&pg=5, 1323anexa14 (accessed on 13 November 2021).

27. Lilja, H.; Christensson, A.; Dahlén, U.; Matikainen, M.T.; Nilsson, O.; Pettersson, K.; Lövgren, T. Prostate-specific antigen in serum occurs predominantly in complex with alpha 1-antichymotrypsin. Clin. Chem. 1991, 37, 1618-1625. [CrossRef]

28. Stenman, U.H.; Leinonen, J.; Alfthan, H.; Rannikko, S.; Tuhkanen, K.; Alfthan, O. A complex between prostate-specific antigen and alpha 1-antichymotrypsin is the major form of prostate-specific antigen in serum of patients with prostatic cancer: Assay of the complex improves clinical sensitivity for cancer. Cancer Res. 1991, 51, 222. [PubMed]

29. Makarov, D.V.; Loeb, S.; Getzenberg, R.H.; Partin, A.W. Biomarkers for prostate cancer. Annu. Rev. Med. 2009, 60, 139-151. [CrossRef] [PubMed]

30. Partin, A.W.; Brawer, M.K.; Subong, E.N.P.; Kelley, C.A.; Cox, J.L.; Bruzek, D.J.; Pannek, J.; E Meyer, G.; Chan, D.W. Prospective evaluation of percent free-PSA and complexed-PSA for early detection of prostate cancer. Prostate Cancer Prostatic Dis. 1998, 1, 197-203. [CrossRef]

31. Arcangeli, C.G.; Humphrey, P.A.; Smith, D.S.; Harmon, T.J.; Shepherd, D.L.; Keetch, D.W.; Catalona, W.J. Percentage of free serum prostate-specific antigen as a predictor of patho-logical features of prostate cancer in a screening population. Urology 1998, 51, 558-564. [CrossRef]

32. Catalona, W.; Partin, A.; Slawin, K.; Brawer, M.; Flanigan, R.; Patel, A.; Richie, J.; Dekernion, J.; Walsh, P.; Scardino, P.; et al. Use of the Percentage of Free Prostate-Specific Antigen to Enhance Differentiation of Prostate Cancer From Benign Prostatic Disease: A Prospective Multicenter Clinical Trial. J. Urol. 1999, 161, 353-354. [CrossRef] 
33. Sturgeon, C.M.; Duffy, M.J.; Stenman, U.H.; Lilja, H.; Brunner, N.; Chan, D.W.; Babaian, R.; Bast, R.C., Jr.; Dowell, B.; Esteva, F.J.; et al. National Academy of Clinical Biochemistry laboratory medicine practice guidelines for use of tumor markers in testicular, prostate, colorectal, breast, and ovarian cancers. Clin. Chem. 2008, 54, e11-e79. [CrossRef]

34. Björk, T.; Ljungberg, B.; Piironen, T.; Abrahamsson, P.-A.; Pettersson, K.; Cockett, A.T.; Lilja, H. Rapid Exponential Elimination of Free Prostate-Specific Antigen Contrasts the Slow, Capacity-Limited Elimination of PSA Complexed to Alpha1-Antichymotrypsin From Serum. Urology 1998, 51, 57-62. [CrossRef]

35. Brawer, M.K.; Meyer, G.E.; Letran, J.L.; Bankson, D.D.; Morris, D.L.; Yeung, K.K.; Allard, W. Measurement of complexed PSA improves specificity for early detection of prostate cancer. Urology 1998, 52, 372-378. [CrossRef]

36. Partin, A.W.; Brawer, M.K.; Bartsch, G.; Horninger, W.; Taneja, S.S.; Lepor, H.; Babaian, R.; Childs, S.J.; Stamey, T.; Fritsche, H.A.; et al. Complexed Prostate Specific Antigen Improves Specificity for Prostate Cancer Detection: Results of a Prospective Multicenter Clinical Trial. J. Urol. 2003, 170, 1787-1791. [CrossRef] [PubMed]

37. DeAntoni, E.P. Age-specific reference ranges for PSA in the detection of prostate cancer. Oncology 1997, 11, 475-482. [PubMed]

38. Lankford, S.P.; Peters, K.L.; Elser, R.C. Potential Effects of Age-Specific Reference Ranges for Serum Prostate-Specific Antigen. Eur. Urol. 1995, 27, 182-186. [CrossRef]

39. Reissigl, A.; Pointner, J.; Horninger, W.; Ennemoser, O.; Strasser, H.; Klocker, H.; Bartsch, G. Comparison of different prostatespecific antigen cutpoints for early detection of prostate cancer: Results of a large screening study. Urology 1995, 46, 662-665. [CrossRef]

40. Wieder, J.A.; Belldegrun, A.S. The Utility of PSA Doubling Time to Monitor Prostate Cancer Recurrence. Mayo Clin. Proc. 2001, 76, 571-572. [CrossRef]

41. Carter, H.B.; Pearson, J.D.; Metter, E.J.; Brant, L.J.; Chan, D.W.; Andres, R.; Fozard, J.L.; Walsh, P.C. Longitudinal evaluation of prostate-specific antigen levels in men with and without prostate disease. JAMA 1992, 267, 2215-2220. [CrossRef]

42. Carter, H.B.; Coey, D.S. The prostate: An increasing medical problem. Prostate 1990, 16, 39-48. [CrossRef]

43. Vickers, A.J.; Savage, C.; O’Brien, M.F.; Lilja, H. Systematic Review of Pretreatment Prostate-Specific Antigen Velocity and Doubling Time As Predictors for Prostate Cancer. J. Clin. Oncol. 2009, 27, 398-403. [CrossRef]

44. Wolters, T.; Roobol, M.J.; Bangma, C.H.; Schröder, F.H. Is Prostate-Specific Antigen Velocity Selective for Clinically Significant Prostate Cancer in Screening? European Randomized Study of Screening for Prostate Cancer (Rotterdam). Eur. Urol. 2009, 55, 385-393. [CrossRef] [PubMed]

45. Benson, M.C.; Whang, I.S.; Pantuck, A.; Ring, K.; Kaplan, S.A.; Olsson, C.A.; Cooner, W.H. Prostate Specific Antigen Density: A Means of Distinguishing Benign Prostatic Hypertrophy and Prostate Cancer. J. Urol. 1992, 147, 815-816. [CrossRef]

46. Polascik, T.J.; Oesterling, J.E.; Partin, A.W. Prostate specific antigen: A decade of discovery-what we have learned and where we are going. J. Urol. 1999, 162, 293-306. [CrossRef]

47. Kalish, J.; Cooner, W.H.; Graham, S.D., Jr. Serum PSA adjusted for volume of transition zone (PSAT) is more ac-curate than PSA adjusted for total gland volume (PSAD) in detecting adenocarcinoma of the prostate. Urology 1994, 43, 601. [CrossRef]

48. Kikuchi, E.; Nakashima, J.; Ishibashi, M.; Ohigashi, T.; Asakura, H.; Tachibana, M.; Murai, M. Prostate specific antigen adjusted for transition zone volume: The most powerful method for detecting prostate carcinoma. Cancer 2000, 89, 842. [CrossRef]

49. Yilmaz, S.N.; Yildiz, A.; Ayyıldız, S.N.; Ayyıldız, A. PSA, PSA derivatives, proPSA and prostate health index in the diagnosis of prostate cancer. Turk. J. Urol. 2014, 40, 82-88. [CrossRef] [PubMed]

50. Bangma, C.; Wildhagen, M.; Yurdakul, G.; Schroder, F.; Blijenberg, B. The value of $(-7,-5)$ pro-prostate-specific antigen and human kallikrein-2 as serum markers for grading prostate cancer. BJU Int. 2004, 93, 720-724. [CrossRef] [PubMed]

51. Chan, T.Y.; Mikolajczyk, S.D.; Lecksell, K.; Shue, M.J.; Rittenhouse, H.G.; Partin, A.W.; Epstein, J.I. Immunohistochemical staining of prostate cancer with monoclonal antibodies to the precursor of prostate-specific antigen. Urology 2003, 62, 177-181. [CrossRef]

52. Sokoll, L.J.; Sanda, M.G.; Feng, Z.; Kagan, J.; Mizrahi, I.A.; Broyles, D.L.; Partin, A.W.; Srivastava, S.; Thompson, I.M.; Wei, J.T.; et al. A Prospective, Multicenter, National Cancer Institute Early Detection Research Network Study of [-2]proPSA: Improving Prostate Cancer Detection and Correlating with Cancer Aggressiveness. Cancer Epidemiol. Biomark. Prev. 2010, 19, 1193-1200. [CrossRef]

53. Mikolajczyk, S.D.; Rittenhouse, H.G. Pro PSA: A more cancer specific form of prostate specific antigen for the early detection of prostate cancer. Keio J. Med. 2003, 52, 86-91. [CrossRef]

54. Leymarie, N.; Griffin, P.J.; Jonscher, K.; Kolarich, D.; Orlando, R.; McComb, M.; Zaia, J.; Aguilan, J.; Alley, W.R.; Altmann, F.; et al. Interlaboratory Study on Differential Analysis of Protein Glycosylation by Mass Spectrometry: The ABRF Glycoprotein Research Multi-Institutional Study 2012. Mol. Cell. Proteom. 2013, 12, 2935-2951. [CrossRef]

55. Gilgunn, S.; Conroy, P.J.; Saldova, R.; Rudd, P.M.; O'Kennedy, R.J. Aberrant PSA glycosylation-A sweet predictor of prostate cancer. Nat. Rev. Urol. 2013, 10, 99-107. [CrossRef] [PubMed]

56. Klein, E.A.; Chait, A.; Hafron, J.M.; Kernen, K.M.; Manickam, K.; Stephenson, A.J.; Wagner, M.; Zhu, H.; Kestranek, A.; Zaslavsky, B.; et al. The Single-parameter, Structure-based IsoPSA Assay Demonstrates Improved Diagnostic Accuracy for Detection of Any Prostate Cancer and High-grade Prostate Cancer Compared to a Concentration-based Assay of Total Prostatespecific Antigen: A Preliminary Report. Eur. Urol. 2017, 72, 942-949. [CrossRef] [PubMed]

57. Stovsky, M.; Klein, E.A.; Chait, A.; Manickam, K.; Stephenson, A.J.; Wagner, M.; Dineen, M.; Lotan, Y.; Partin, A.; Baniel, J.; et al. Clinical Validation of IsoPSA ${ }^{\mathrm{TM}}$, a Single Parameter, Structure Based Assay for Improved Detection of High Grade Prostate Cancer. J. Urol. 2019, 201, 1115-1120. [CrossRef] [PubMed] 
58. Sharma, U.; Pal, D.; Prasad, R. Alkaline Phosphatase: An Overview. Indian J. Clin. Biochem. 2014, 29, 269-278. [CrossRef]

59. Groot, M.; Kruger, C.B.; Pelger, R.; Groot, C.U.-D. Costs of Prostate Cancer, Metastatic to the Bone, in The Netherlands. Eur. Urol. 2003, 43, 226-232. [CrossRef]

60. Li, D.; Lv, H.; Hao, X.; Hu, B.; Song, Y. Prognostic value of serum alkaline phosphatase in the survival of prostate cancer: Evidence from a meta-analysis. Cancer Manag. Res. 2018, ume 10, 3125-3139. [CrossRef]

61. Barbosa, F.G.; Queiroz, M.A.; Ferraro, D.A.; Nunes, R.F.; Dreyer, P.R.; Zaniboni, E.C.; Costa, L.B.; Bastos, D.A.; Marin, J.F.G.; Buchpiguel, C.A. Prostate-specific Membrane Antigen PET: Therapy Response Assessment in Metastatic Prostate Cancer. Radiogr. 2020, 40, 1412-1430. [CrossRef]

62. Perner, S.; Hofer, M.D.; Kim, R.; Shah, R.B.; Li, H.; Möller, P.; Hautmann, R.E.; Gschwend, J.E.; Kuefer, R.; Rubin, M.A. Prostate-specific membrane antigen expression as a predictor of prostate cancer progression. Hum. Pathol. 2007, 38, 696-701. [CrossRef]

63. Hupe, M.C.; Philippi, C.; Roth, D.; Kümpers, C.; Ribbat-Idel, J.; Becker, F.; Joerg, V.; Duensing, S.; Lubczyk, V.H.; Kirfel, J.; et al. Expression of Prostate-Specific Membrane Antigen (PSMA) on Biopsies Is an Independent Risk Stratifier of Prostate Cancer Patients at Time of Initial Diagnosis. Front. Oncol. 2018, 8, 623. [CrossRef]

64. Nagaya, N.; Nagata, M.; Lu, Y.; Kanayama, M.; Hou, Q.; Hotta, Z.-U.; China, T.; Kitamura, K.; Matsushita, K.; Isotani, S.; et al. Prostate-specific membrane antigen in circulating tumor cells is a new poor prognostic marker for castration-resistant prostate cancer. PLoS ONE 2020, 15, e0226219. [CrossRef]

65. Vlachostergios, P.; Zachos, I.; Tzortzis, V. Biomarkers in Prostate-Specific Membrane Antigen Theranostics. Diagnostics 2021, 11, 1108. [CrossRef]

66. Catalona, W.J.; Partin, A.W.; Sanda, M.G.; Wei, J.T.; Klee, G.G.; Bangma, C.H.; Slawin, K.M.; Marks, L.S.; Loeb, S.; Broyles, D.L.; et al. A Multicenter Study of [-2]Pro-Prostate Specific Antigen Combined With Prostate Specific Antigen and Free Prostate Specific Antigen for Prostate Cancer Detection in the 2.0 to $10.0 \mathrm{ng} / \mathrm{ml}$ Prostate Specific Antigen Range. J. Urol. 2011, 185, 1650-1655. [CrossRef]

67. Filella, X.; Gimenez, N. Evaluation of [-2] proPSA and prostate health index (phi) for the detection of prostate cancer: A systematic review and meta-analysis. Clin. Chem. Lab. Med. 2013, 51, 729-739. [CrossRef] [PubMed]

68. Duffy, M.J. Biomarkers for prostate cancer: Prostate-specific antigen and beyond. Clin. Chem. Lab. Med. 2020, 58, 326-339. [CrossRef]

69. Jansen, F.H.; van Schaik, R.H.; Kurstjens, J.; Horninger, W.; Klocker, H.; Bektic, J.; Wildhagen, M.F.; Roobol, M.J.; Bangma, C.H.; Bartsch, G. Prostate-Specific Antigen (PSA) Isoform p2PSA in Combination with Total PSA and Free PSA Improves Diagnostic Accuracy in Prostate Cancer Detection. Eur. Urol. 2010, 57, 921-927. [CrossRef] [PubMed]

70. De La Calle, C.; Patil, D.; Wei, J.T.; Scherr, D.S.; Sokoll, L.; Chan, D.W.; Siddiqui, J.; Mosquera, J.M.; Rubin, M.A.; Sanda, M.G. Multicenter evaluation of the prostate health index to detect aggressive prostate cancer in biopsy naive men. J. Urol. 2015, 194, 65-72. [CrossRef]

71. Loeb, S.; Sanda, M.G.; Broyles, D.L.; Shin, S.S.; Bangma, C.H.; Wei, J.T.; Partin, A.W.; Klee, G.G.; Slawin, K.M.; Marks, L.S.; et al. The Prostate Health Index Selectively Identifies Clinically Significant Prostate Cancer. J. Urol. 2015, 193, 1163-1169. [CrossRef] [PubMed]

72. Olleik, G.; Kassouf, W.; Aprikian, A.; Hu, J.; Vanhuyse, M.; Cury, F.; Peacock, S.; Bonnevier, E.; Palenius, E.; Dragomir, A. Evaluation of New Tests and Interventions for Prostate Cancer Management: A Systematic Review. J. Natl. Compr. Cancer Netw. 2018, 16, 1340-1351. [CrossRef]

73. Lughezzani, G.; Lazzeri, M.; Buffi, N.M.; Abrate, A.; Mistretta, F.A.; Hurle, R.; Pasini, L.; Castaldo, L.; De Zorzi, S.Z.; Peschechera, R.; et al. Preoperative prostate health index is an independent predictor of early biochemical recurrence after radical prostatectomy: Results from a prospective single-center study. Urol. Oncol. 2015, 33, 337.e7-337.e14. [CrossRef]

74. Hsieh, P.-F.; Li, W.-J.; Lin, W.-C.; Chang, H.; Chang, C.-H.; Huang, C.-P.; Yang, C.-R.; Chen, W.-C.; Chang, Y.-H.; Wu, H.-C. Combining prostate health index and multiparametric magnetic resonance imaging in the diagnosis of clinically significant prostate cancer in an Asian population. World J. Urol. 2020, 38, 1207-1214. [CrossRef] [PubMed]

75. Bussemakers, M.J.; Van Bokhoven, A.; Verhaegh, G.W.; Smit, F.P.; Karthaus, H.F.; Schalken, J.A.; Debruyne, F.M.; Ru, N.; Isaacs, W.B. DD3: A new prostate-specific gene, highly overexpressed in prostate cancer. Cancer Res. 1999, 59, 5975-5979.

76. Filella, X.; Fernández-Galán, E.; Bonifacio, R.F.; Foj, L. Emerging biomarkers in the diagnosis of prostate cancer. Pharm. Pers. Med. 2018, ume 11, 83-94. [CrossRef]

77. Salami, S.S.; Schmidt, F.; Laxman, B.; Regan, M.M.; Rickman, D.S.; Scherr, D.; Bueti, G.; Siddiqui, J.; Tomlins, S.A.; Wei, J.T.; et al. Combining urinary detection of TMPRSS2:ERG and PCA3 with serum PSA to predict diagnosis of prostate cancer. Urol. Oncol. Semin. Orig. Investig. 2013, 31, 566-571. [CrossRef] [PubMed]

78. Fenner, A. PCA3 as a Grade Reclassification Predictor. Nat. Rev. Urol. 2017, 14, 390. [CrossRef] [PubMed]

79. Schröder, F.H.; Venderbos, L.D.; Bergh, R.C.V.D.; Hessels, D.; van Leenders, G.J.; van Leeuwen, P.J.; Wolters, T.; Barentsz, J.O.; Roobol, M.J. Prostate Cancer Antigen 3: Diagnostic Outcomes in Men Presenting With Urinary Prostate Cancer Antigen 3 Scores $\geq 100$. Urology 2014, 83, 613-616. [CrossRef] [PubMed]

80. Tomlins, S.A.; Day, J.R.; Lonigro, R.J.; Hovelson, D.H.; Siddiqui, J.; Kunju, L.P.; Dunn, R.L.; Meyer, S.; Hodge, P.; Groskopf, J.; et al. Urine TMPRSS2:ERG Plus PCA3 for Individualized Prostate Cancer Risk Assessment. Eur. Urol. 2016, 70, 45-53. [CrossRef] 
81. Alford, A.V.; Brito, J.M.; Yadav, K.K.; Yadav, S.S.; Tewari, A.K.; Renzulli, J. The Use of Biomarkers in Prostate Cancer Screening and Treatment. Rev. Urol. 2017, 19, 221-234. [CrossRef] [PubMed]

82. Kornberg, Z.; Cooperberg, M.R.; Spratt, D.E.; Feng, F.Y. Genomic biomarkers in prostate cancer. Transl. Androl. Urol. 2018, 7, 459-471. [CrossRef]

83. Vickers, A.J.; Cronin, A.M.; Aus, G.; Pihl, C.-G.; Becker, C.; Pettersson, K.; Scardino, P.T.; Hugosson, J.; Lilja, H. A panel of kallikrein markers can reduce unnecessary biopsy for prostate cancer: Data from the European Randomized Study of Prostate Cancer Screening in Göteborg, Sweden. BMC Med. 2008, 6, 19. [CrossRef]

84. Filella, X.; Foj, L. Emerging biomarkers in the detection and prognosis of prostate cancer. Clin. Chem. Lab. Med. 2015, 53, 963-973. [CrossRef]

85. Munteanu, V.C.; Munteanu, R.A.; Gulei, D.; Schitcu, V.H.; Petrut, B.; Berindan Neagoe, I.; Achimas Cadariu, P.; Coman, I. PSA Based Biomarkers, Imagistic Techniques and Combined Tests for a Better Diagnostic of Localized Prostate Cancer. Diagnostics 2020, 10, 806. [CrossRef] [PubMed]

86. Vickers, A.J.; Ms, A.M.C.; Aus, G.; Pihl, C.-G.; Becker, C.; Pettersson, K.; Scardino, P.T.; Hugosson, J.; Lilja, H. Impact of recent screening on predicting the outcome of prostate cancer biopsy in men with elevated prostate-specific antigen. Cancer 2010, 116, 2612-2620. [CrossRef]

87. Parekh, D.J.; Punnen, S.; Sjoberg, D.D.; Asroff, S.W.; Bailen, J.L.; Cochran, J.S.; Concepcion, R.; David, R.D.; Deck, K.B.; Dumbadze, I.; et al. A multi-institutional prospective trial in the USA confirms that the 4Kscore accu-rately identifies men with high-grade prostate cancer. Eur Urol. 2015, 68, 464-470. [CrossRef] [PubMed]

88. Kohaar, I.; Petrovics, G.; Srivastava, S. A Rich Array of Prostate Cancer Molecular Biomarkers: Opportunities and Challenges. Int. J. Mol. Sci. 2019, 20, 1813. [CrossRef] [PubMed]

89. Russo, G.I.; Regis, F.; Castelli, T.; Favilla, V.; Privitera, S.; Giardina, R.; Cimino, S.; Morgia, G. A systematic review and metaanalysis of the diagnostic accuracy of prostate health index and 4-kallikrein panel score in predicting overall and high-grade prostate cancer. Clin. Genitourin. Cancer 2017, 15, 429-439. [CrossRef] [PubMed]

90. Rector, T.S.; Taylor, B.C.; Wilt, T.J. Systematic review of prognostic tests. In Methods Guide for Medical Test Reviews; Chang, S.M., Matchar, D.B., Smetana, G.W., Umscheid, C.A., Eds.; Agency for Healthcare Research and Quality: Rockville, MD, USA, 2012; Chapter 12.

91. Ström, P.; Nordström, T.; Aly, M.; Egevad, L.; Grönberg, H.; Eklund, M. The Stockholm-3 Model for Prostate Cancer Detection: Algorithm Update, Biomarker Contribution, and Reflex Test Potential. Eur. Urol. 2018, 74, 204-210. [CrossRef] [PubMed]

92. Grönberg, H.; Eklund, M.; Picker, W.; Aly, M.; Jäderling, F.; Adolfsson, J.; Landquist, M.; Haug, E.S.; Ström, P.; Carlsson, S.; et al. Prostate Cancer Diagnostics Using a Combination of the Stockholm3 Blood Test and Multiparametric Magnetic Resonance Imaging. Eur. Urol. 2018, 74, 722-728. [CrossRef] [PubMed]

93. Sharp, A.; Coleman, I.; Yuan, W.; Sprenger, C.; Dolling, D.; Rodrigues, D.N.; Russo, J.W.; Figueiredo, I.; Bertan, C.; Seed, G.; et al. Androgen receptor splice variant-7 expression emerges with castration resistance in prostate cancer. J. Clin. Investig. 2018, 129, 192-208. [CrossRef]

94. Friedlander, T.W.; Pritchard, C.C.; Beltran, H. Personalizing Therapy for Metastatic Prostate Cancer: The Role of Solid and Liquid Tumor Biopsies. Am. Soc. Clin. Oncol. Educ. Book 2017, 37, 358-369. [CrossRef]

95. Markowski, M.C.; Silberstein, J.L.; Eshleman, J.R.; Eisenberger, M.A.; Luo, J.; Antonarakis, E.S. Clinical Utility of CLIA-Grade AR-V7 Testing in Patients With Metastatic Castration-Resistant Prostate Cancer. JCO Precis. Oncol. 2017, 2017, 1-9. [CrossRef]

96. Shore, N.D.; Kella, N.; Moran, B.; Boczko, J.; Bianco, F.J.; Crawford, E.D.; Davis, T.; Roundy, K.M.; Rushton, K.; Grier, C.; et al. Impact of the Cell Cycle Progression Test on Physician and Patient Treatment Selection for Localized Prostate Cancer. J. Urol. 2016, 195, 612-618. [CrossRef] [PubMed]

97. Cuzick, J.; Swanson, G.P.; Fisher, G.; Brothman, A.R.; Berney, D.M.; Reid, J.E.; Mesher, D.; Speights, V.O.; Stankiewicz, E.; Foster, C.S.; et al. Prognostic value of an RNA expression signature derived from cell cycle proliferation genes in patients with prostate cancer: A retrospective study. Lancet Oncol. 2011, 12, 245-255. [CrossRef]

98. Cuzick, J.; Berney, D.M.; Fisher, G.; Mesher, D.; Møller, H.; Reid, J.E.; Perry, M.; Park, J.; Younus, A.; Gutin, A.; et al. Prognostic value of a cell cycle progression signature for prostate cancer death in a conservatively managed needle biopsy cohort. Br. J. Cancer 2012, 106, 1095-1099. [CrossRef] [PubMed]

99. Mohler, J.L.; Armstrong, A.J.; Bahnson, R.R.; D’Amico, A.V.; Davis, B.; Eastham, J.A.; Enke, C.A.; Farrington, T.A.; Higano, C.S.; Horwitz, E.M.; et al. Prostate Cancer, Version 1.2016. J. Natl. Compr. Cancer Netw. 2016, 14, 19-30. [CrossRef]

100. Dall'Era, M.A.; Maddala, T.; Polychronopoulos, L.; Gallagher, J.R.; Febbo, P.G.; Denes, B.S. Utility of the Oncotype DX ®Prostate Cancer Assay in Clinical Practice for Treatment Selection in Men Newly Diagnosed with Prostate Cancer: A Retrospective Chart Review Analysis. Urol. Pract. 2015, 2, 343-348. [CrossRef]

101. Cullen, J.; Rosner, I.L.; Brand, T.C.; Zhang, N.; Tsiatis, A.C.; Moncur, J.; Ali, A.; Chen, Y.; Knezevic, D.; Maddala, T.; et al. A biopsy-based 17-gene genomic prostate score predicts recurrence after radical prostatectomy and adverse surgical pathology in a racially diverse population of men with clinically low- and intermediate-risk prostate cancer. Eur. Urol. 2015, 68, 123-131. [CrossRef]

102. Brajtbord, J.S.; Leapman, M.S.; Cooperberg, M.R. The CAPRA score at 10 years: Contemporary perspectives and analysis of sup-porting studies. Eur. Urol. 2017, 71, 705-709. [CrossRef] [PubMed] 
103. Klein, E.A.; Cooperberg, M.R.; Magi-Galluzzi, C.; Simko, J.P.; Falzarano, S.M.; Maddala, T.; Chan, J.; Li, J.; Cowan, J.E.; Tsiatis, A.C.; et al. A 17-gene Assay to Predict Prostate Cancer Aggressiveness in the Context of Gleason Grade Heterogeneity, Tumor Multifocality, and Biopsy Undersampling. Eur. Urol. 2014, 66, 550-560. [CrossRef]

104. Cullen, J.; Kuo, H.-C.; Shan, J.; Lu, R.; Aboushwareb, T.; Eeden, S.K.V.D. The 17-Gene Genomic Prostate Score Test as a Predictor of Outcomes in Men with Unfavorable Intermediate Risk Prostate Cancer. Urol. 2020, 143, 103-111. [CrossRef]

105. Zhao, S.G.; Chang, S.L.; Spratt, D.E.; Erho, N.; Yu, M.; Ashab, H.A.D.; Alshalalfa, M.; Speers, C.; Tomlins, S.A.; Davicioni, E.; et al. Development and validation of a 24-gene predictor of response to postoperative radiotherapy in prostate cancer: A matched, retrospective analysis. Lancet Oncol. 2016, 17, 1612-1620. [CrossRef]

106. Erho, N.; Crisan, A.; Vergara, I.A.; Mitra, A.P.; Ghadessi, M.; Buerki, C.; Bergstralh, E.J.; Kollmeyer, T.; Fink, S.; Haddad, Z.; et al. Discovery and validation of a prostate cancer genomic classifier that predicts early metastasis following radical prostatectomy. PLoS ONE 2013, 8, e66855.

107. Dalela, D.; Santiago-Jiménez, M.; Yousefi, K.; Karnes, R.J.; Ross, A.E.; Den, R.B.; Freedland, S.J.; Schaeffer, E.M.; Dicker, A.P.; Menon, M.; et al. Genomic classifier augments the role of pathological features in identifying optimal candidates for adjuvant radiation therapy in patients with prostate cancer: Development and internal validation of a multivariable prognostic model. J. Clin. Oncol. 2017, 35, 1982-1990. [CrossRef]

108. Cucchiara, V.; Cooperberg, M.R.; Dall’Era, M.; Lin, D.W.; Montorsi, F.; Schalken, J.A.; Evans, C.P. Genomic Markers in Prostate Cancer Decision Making. Eur. Urol. 2018, 73, 572-582. [CrossRef]

109. Moul, J.W. Prostate specific antigen only progression of prostate cancer. J. Urol. 2000, 163, 1632-1642. [CrossRef]

110. Roach, M., III; Hanks, G.; Thames, H., Jr.; Schellhammer, P.; Shipley, W.U.; Sokol, G.H.; Sandler, H. Defining biochemical failure following radiotherapy with or without hormonal therapy in men with clinically localized prostate cancer: Recommendations of the RTOG-ASTRO Phoenix Consensus Conference. Int. J. Radiat. Oncol. Biol. Phys. 2006, 65, 965-974. [CrossRef]

111. Jairath, N.K.; Pra, A.D.; Vince, R.; Dess, R.T.; Jackson, W.C.; Tosoian, J.J.; McBride, S.M.; Zhao, S.G.; Berlin, A.; Mahal, B.A.; et al. A Systematic Review of the Evidence for the Decipher Genomic Classifier in Prostate Cancer. Eur. Urol. 2021, 79, 374-383. [CrossRef]

112. NCCN. Clinical Practice Guidelines in Oncology_Prostate Cancer. Available online: https://www.nccn.org/professionals/ physician_gls/pdf/prostate.pdf (accessed on 13 November 2021).

113. Leyten, G.H.J.M.; Hessels, D.; Smit, F.P.; Jannink, S.A.; De Jong, H.; Melchers, W.; Cornel, E.B.; De Reijke, T.M.; Vergunst, H.; Kil, P.; et al. Identification of a Candidate Gene Panel for the Early Diagnosis of Prostate Cancer. Clin. Cancer Res. 2015, 21, 3061-3070. [CrossRef]

114. Van Neste, L.; Hendriks, R.J.; Dijkstra, S.; Trooskens, G.; Cornel, E.B.; Jannink, S.A.; de Jong, H.; Hessels, D.; Smit, F.P.; Melchers, W.J.; et al. Detection of high-grade prostate cancer using a urinary molecular biomarker-based risk score. Eur. Urol. 2016, 70, 740-748. [CrossRef] [PubMed]

115. Lendínez-Cano, G.; Ojeda-Claro, A.V.; Gómez-Gómez, E.; Jimenez, P.M.; Martin, J.F.; Dominguez, J.F.; Amores, J.; Cozar, J.M.; Bachiller, J.; Juárez, A.; et al. Prospective study of diagnostic accuracy in the detection of high-grade prostate cancer in biopsynaïve patients with clinical suspicion of prostate cancer who underwent the Select MDx test. Prostate 2021, 81, 857-865. [CrossRef] [PubMed] 